\title{
Social Economic Empowerment for Ex-prostitutes and the Impacted Residents after Dolly and Jarak Closures
}

\author{
Mutimmatul Faidah, Biyan Yesi Wilujeng, Imami \\ Arum Tri Rahayu \\ Department of Home Economic \\ Universitas Negeri Surabaya \\ Surabaya,Indonesia \\ mutimmatulfaidah@unesa.ac.id
}

\author{
Hery Rusmanto \\ Universitas Islam Negeri Sunan Ampel Surabaya \\ Surabaya,Indonesia
}

\begin{abstract}
Dolly and Jarak are two bigger prostitutions in Surabaya, Indonesia before its closures in 2014. The closure still raises discussive issues in accordance with the closure itself and the forceful effort to return the prostitutes back home. This Participatory Action Research (PAR) used diverse subjects including the ex-prostitutes, the impacted residents, and the local government. Data were collected through interview, observation, and focus group discussion. Result showed that there exists the lacks of diversified culinary business and the low prices of products due to unstandardized management done by the local residents, the abnormal economic cycle, and the unintegrated religious training. Another interesting result showed that it was developed an empowerment model by giving various trainings and assistances covering soft skill, management and marketing, networking, entrepreneurship, and mental and spiritual to accelerate the social economic condition of the ex-prostitution area.
\end{abstract}

Keywords-mental; makeup; skills; ex-prostitutes

\section{INTRODUCTION}

There are six big prostitutions in Surabaya, Indonesia, namely Dolly, Jarak, Moroseneng-Sememi, Dupak Bangunsari, Tambak Asri-Kremil and Klakahrejo, of which have been closed since 2013. In 2014, a closure was done to Dolly and Jarak that consisted 312 prostitution houses, 300 procurers, and about 1,600 prostitutes [1]. The closure was not a means of forcing the prostitutes back to their hometowns, rather, they still lived in Surabaya with different job opportunities such as housewives, dish cleaners, house maids, food sellers, culinary and batik entrepreneurs, and other professions [2]. The exprostitutes are actually included in a mentally and economically susceptible community, so that, they need a character and skill empowerment as a strategic modal to begin a start-up.

The process of closing and returning the ex-prostitutes of Dolly and Jarak still remains unsolved problems, such as (1) ex-prostitutes' mental and spiritual instability in living normally among societies, (2) the temptation for coming back to being a prostitute through either online or black prostitution,
(3) limited skills that can be applied in different better opportunities, (4) unreadiness of tranmigrating to their hometown, and (5) ex-prostitutes' problems regarding diverse excuses to keep staying in Surabaya. Thus, if only there is no empowerment for the ex-prostitutes, it is likely possible to happen another social problem such as the movements of them from prostitution to some hidden prostitutions like in small stalls, massage parlors, or other places [3].

Based on the results of field observation and interview to the prominent figure in society, data showed that the closure impacted significantly to the ex-prostitutes and the nearby residents. First, based on a social aspect, the ex-prostitutes were still difficult to significantly elicit their bad self-labels. Moreover, changing the self-label needed harder efforts as it was difficult and spent longer periodic times. Second, referring to cultural aspect, the routines as prostitutes could not be easily altered as the previous lifestyle, behavior, speaking tone and style, and habit were tightly attached to themselves. As a result, they experienced social confrontation with the neighboring people, regardless their new status even not being a prostitute any longer. Third, the problem dealt with economic aspect [4]. Most prostitutes were dependent to the income they got from the prostitution practice in which the condition made them face difficulties as the presence of massive closures. To cope with that, the ex-prostitutes found economic problems to survive living which then led them to deal with physically hard jobs such as being maids. This severe and catastrophic economic issue might trigger their consideration to rework as a prostitute.

\section{METHOD}

By referring to above initial problems, this research aims to pattern the problems and the ex-localization residents' potential ability and to describe empowerment pattern for the exprostitutes and the impacted residents by strengthening mental and skill modals. This research was done by approaching to Participatory Action Research (PAR), a community empowerment model by involving society in each empowering process [5]. The research participants were the ex-prostitutes, the impacted residents and the local government. Data were 
collected through interview, observation and focus group discussion (FGD).

\section{RESULTS AND DISCUSSION}

\section{A. Community Empowerment Concept}

Community development, or known as community empowerment, is an effort to make society independent through establishing owned potential and skill [6]. The essence of empowerment lies differently from what is known as addiction. That is, a social development program does not prior to charitable or punitive-based programs, rather the empowering program that has people-centered, participatory, empowering, and sustainable characteristics [7]. Empowerment focuses on individual or community's ability, especially the susceptible and weak community, to possess accesses in productive resources that may have them get necessary goods or services and participate in a development and influential decision making process. It also priors to reallocating efforts of power through the change of social structure [8]. In other words, it contains meaning of improving each individual's and society's living quality or welfare including economic, social, independency, security, and basic human right, of which is distant to frightening and doubtful feelings [9].

Efforts of community empowerment can be seen directly from three points. First, it is essential to construct an atmosphere or a climate that enables society to develop their abilities [10]. In this research context, the impacted residents and the procurers are the ones whose abilities or skills need to be explored by arousing and developing an awareness of selfpotentials. Second, it is also necessary to empowering them by organizing strategic steps to open access of diverse opportunities. In accordance with this research, the residents living in surrounding prostitution area should be taught about modernity, covering being hard worker, openness, responsibility and social structure strengthening actions. Third, Empowering means protecting as an effort to prevent imbalance, exploitation and any other forms that make society depend on what has been given from others.

This research used Participatory Action Research (PAR), a process where a social community tries to conduct a scientific case study to lead, improve, and evaluate their decision and performance [11]. PAR is closed to three important terms which are interconnected as a cycle namely participation, research, and action. There are four major cyclical steps covering planning, acting, observing, and reflecting. To empower the impacted residents using the local potential and people's self and local property, the researchers, in this case, approached the idea of Asset Based Community Development [12] in each planed stage that will focus on; (1) a pattern of the residents' challenges and potentials, (2) assets owned and residents' power to face any problems, (3) skill, mobility, and real portrayed citizens' identification, (4) community empowerment done by international scholars, and (5) the already formed networking.

\section{B. Problem Mapping and Empowerment Patteern of Those in the Ex-prostitution Areas}

The Dolly and Jarak prostitutions are located in a busy populous area. The presence of this business gives multiplying effects in economic sector shown by a cyclical money used up to 3 trillion rupiahs per night. There are 10 sectors with 34 job positions that are either directly or incidentally involved and impacted, such as; (1) prostitution sector, including procurers, prostitutes, and match-makers, (2) the landlords that make his house be prostitution places, (3) cleaning service, covering laundresses, and dish and housing cleaners, (4) transportation sector, involving driver, owner of car or motor rent, driver service, and pedicabman, (5) beautician or therapist, (6) food and beverage sellers, covering those who sell snack, beverage, cigarettes, main course, alcoholic drink, or any foods in small stalls, (7) safety, including but not limited to security, parking guard, and soon, (8) health and supernatural, namely midwife, paranormal, drug store, Indonesia traditional secret poison/jamu, masseuses, and any other magical-based activities, (9) entertainment, covering karaoke, waiter, beggar, and dancer, and (10) financial service in Bank Titil (a renterlike bank) [2].

Dolly closure was conducted without any relocation applied on June 2014, of which then creates numbers of conflicts. Nowadays, both Putat Jaya and Jarak become a desolated-like area and face economic immobility. Couples of spare residents are on sales and rented. Not so few houses are transformed into different economic modal, such as being café and music house that employ the ex-prostitutes as singers and waitresses. Even up to this day, Dolly and Jarak are still under city's restoration as the people's economic cycle is being likely stagnant.

First, there is a similarity of the products produced by either the ex-prostitutes or the impacted residents with those in today's markets, i.e. salty egg, cookies, nugget, sambal, bread and soon. These food products have no legal business permission from the government and no halal legality from MUI, a government organization which controls permitted usage of particular goods and foods. The intervention done by the partnerships and Corporate Social Responsibility (CSR) is just limited to training to make foods, bazaar, and culinary exhibition. The lack of culinary production is caused by the limited skills possessed by residents to diversify their products.

Referring to the fact that the focuses of empowerment to be launched are (a) training of product's quality development, (b) diversification training in making foods, (c) assistance of arranging production legality, (d) assistance of marketing, (e) assistance of registering business permission and halal certification, (f) training on value-added product development, and (g) developing networking by cooperating with both government and private sectors. Those efforts are a series of breakthrough which is expected to realize product diversification and culinary center as the forerunner of culinary tourism in the ex-prostitution areas, especially in Dolly and Jarak.

Second, in coping with batik production arranged by the people in Dolly and Jarak, they have limited production only on hand-made batik motives. The orders are mostly from the famous stores that demand their batik products. The 
government's intervention is only limited to the training of handmade batik and builds cooperation with another batik production named "Risma". Empowerment efforts to be developed include (a) training on the making of new batik design and motif, (b) handprint batik training, (c) assistance of beginning a startup, and (d) giving a continued modal. The target of this empowerment program is the presence of batik industry in the ex-prostitution area.

Third, people's productive enterprises are still in a form of individual scaled in a household level, in this case known as a production of handicraft. Intervention done by CSR is aimed to giving handicraft training and a startup modal. In this research, PAR focuses on (a) training in developing product's quality, (b) making a group of handcrafters, (c) marketing product and assisting on it, (d) building networking with many government and private sectors as markets.

Fourth, it is necessary to enhance the skills needed in a makeup service as the people in charge of this kind of service still perform minimum. PAR helps to conduct (a) training on improving qualified service, (b) assistance of making a makeup brand, (c) assistance of marketing service, and (d) enlarging networking with related customers in needs as marketing strategy. By those various efforts of empowerment, it is expected that they possess standard qualification and capacity in running their makeup enterprises, and are hoped to continue the business, yet the current presence of a new makeup brand, and visible and applicable promotion through any forms of media.

Fifth, their economic cycle can be back to normal settings and experiences an acceleration of diverse transformation, i.e. from massive home prostitution to productive enterprises such as a culinary center, tourism village, and many more as the results of cooperating with $\mathrm{CSR}$, the local government, and other related stakeholders.

Sixth, religious empowerment given to the all exes is still in a form of traditional lecturing mode, no integrated and systematic model either from the topics or themes or the contents. PAR focuses on the construction of both the exprostitutes' mentality and spirituality start with developing proper syllabus along with the module. Therefore, the empowerment model of this issue can be more systematic and integrated, of which further excels with of what think to change.

The social problem presented in the ex-prostitution area is the presence of prostitutes in café and music houses. In accordance with the problem, the local government needs to conduct a cooperated inspection between the nearby residents and the local government since the sudden inspection done by one of police regiments is not that successful. The intended cooperated program includes (a) listing the music houses and café in the ex-prostitution area and the nearby locations, (b) identifying the legality of the business, (c) building cooperation with Tourism Office and relevant government stakeholders, (d) empowering people' mental and personality, and (e) activating communication bridge for people to create a social control of the condition of the ex-prostitution area.

\section{SWOT Analysis of the Empowerment Model}

SWOT analysis of the social economic condition in the exprostitution area namely Dolly and Jarak is explained as follows:

\section{1) Strenths}

a) It has been conducted a training on culinary and batik sector to equip the residents with qualified skills.

b) It has been growing productive culinary, foods, batik and seaweed beverage enterprises.

c) It has been exist the new brand startup namely Samijali, Orumy, and Batik Villages which all work in different focused enterprises and businesses.

d) The residents' motivations of moving into better qualified living standard has grown and all intervention of any sectors has also been running well.

e) The residents' motivation of changing the label of Dolly and Jarak into a well-known, comfortable, and interesting tourism places has been done by the presence of colorful houses and preserved green environment.

After the analysis has been done, there are six numbers of what need to do to encounter the analysis results. First, it is necessary to conduct diversification training program relevantly to need assessment and the local assets to encourage residents' varied economic activities. Then, it is important to enhance the production quality and marketing enlargement to improve the product and marketing strategy. Third, building social networking can be more helpful in term of accelerating all programs implemented in the impacted areas. Fourth, strengthening residents' motivation is one of essential empowerment program by conducting mental and personality training. Last but not the least, it is important to strengthen the presence of different focused Villages by improving the residents' belonging to each village and make it as comfortable, environmental friendly, and attractive places to visit for any tourists.

\section{2) Weaknesses.}

a) Culinary business and other foods enterprises have been massive and similar between the residents' products and the current spread products within society as the results of skill lacks.

b) The residents only accept an unready batik order, instead of the ready ones.

c) The residents are paid below the standard in screen printing enterprise because the order is gotten from other similar productions.

d) The residents' aesthetic enterprises are still limited to beautician's assistance.

e) There is no maximum usage of the spare houses in which this results to the residents' low economic level.

f) The presence of music houses and café, ironically, still provides prostitutes to be booked outside the placesSelection: Highlight all author and affiliation lines. 
After the analysis done, there are five important points to be conducted. First, it is important to improve product's quality and its diversities to increase selling points. Second, it is also necessary to conduct training in batik production and screen printing sectors by giving them assistances related to how to begin a startup and marketing strategy including promotion. Third, building social networking starts to be important in any elements of economic activities to accelerate the economic condition. Afterwards, giving a training on makeup service sector will be thought so beneficial for the residents to conduct independent makeup service. Last but not the least, the presence of mental and spiritual empowerment will create a bridge to a social control.

\section{3) Opportunities}

a) Culinary business and food production has a potential commitment to improve the quality of products and services.

b) Batik is nowadays one of the prominent national issues so that the market segments must be widely opened.

c) There is an awareness of diverse elements to conduct recovery intervention the condition of ex-prostitution areas.

After getting the data consisting the opportunities, there are two important things, at least, to be conducted. First, it is crucial to organize a strategy and implementation of improving product's quality, service and the relevant marketing strategy. Another important one is to conduct a workshop interconnecting all related elements or sectors or stakeholders to arrange an integrated steps to restore the condition of the ex-prostitution areas and to make a crisis center.

\section{4) Threats}

There are three crucial threats found in the field. First, there is a bad competition between the residents and others in term of the product's similarity. Second, the culinary business is threatened to be collapsed due to the illogical increase of any costs of raw materials. At last, the hidden music houses and café can decrease the label of the places, so that, it will affect the living coziness there, and even raise the tourists' reluctance to come.

Those three above need to be encountered by conducting at least four issues. First, it is essential to conduct training program to strengthen each product's characteristics and the diversification of business. Second, it is said to be important to increase the price of the products gradually and to cut out unnecessary spending. Third, it is important to do marketing assistance and marketing enlargement. Finally, it can be given a mental and personality empowerment by involving the people in youth community, religious organization and other social control events.

Nowadays, the condition of Dolly and Jarak becomes attractive villages due to colorful houses and green environment. They are now transformed into a better living area with no presence of previous labels. The residents' economic activities are now supported by different elements such as the residents as the subjects of development, university as the initiator of the development, the local government as the inventor of the development, and other stakeholders as the encourager of the development of both physics and morality of Dolly and Jarak residents

After getting the data consisting the opportunities, there are two important things

\section{CONCLUSION}

Based on above explanations, it can be highlighted two important points. First, the challenges are the minimum diversification of culinary businesses or enterprises, the low selling points managed by the local residents, the lacks of business legality verified by the local government, the incorporated business especially in a form of household enterprises, the abnormal economic development, and the lacks of integrated spiritual and mental empowerment. Another important one is about the counter actions including the integrated training, management and marketing training, networking the consumers, entrepreneurship assistance, both mental and spiritual empowerment, and building integrated cooperation with all elements such as society, government, related stakeholders, and academicians to accelerate the changes of the social economic condition in the ex-prostitution areas.

\section{REFERENCES}

[1] Faidah, Mutimmatul. 2014. Model Alih Profesi WTS di Area Lokalisasi. Surabaya: Laporan Penelitian LPPM.

[2] Faidah, Mutimmatul, 2014. "Pusaran Ekonomi Di Balik Bisnis Prostitusi”, Jurnal Lentera. Volume 10, nomor 1, Juni 2014.

[3] Sunarto. Kyai Prostitusi. 2014. Surabaya: ISDIAL-MUI Jatim.

[4] Idial. 2012. Citra Diri Wanita Tuna Susila. Surabaya: Laporan Penelitian tidak diterbitkan.

[5] Kemmis, Stephen and Robin Mc Taggart. 1997. The Action Research Reader. Geelong: Deakin University.

[6] Mardikanto, Totok. 2010. Konsep-Konsep Pemberdayaan Masyarakat. Surakarta: UNS Press.

[7] Suharto, Edy. 2010. Membangun Masyarakat Memberdayakan Rakyat: Kajian Sinergi Pembangunan Kesejahteraan Sosial dan Pekerjaan Sosial. Bandung: Rafika.

[8] Sriglitz, J E. 2002. Participation and Development: Perspectives from the Comprehensive Development Paradigm. Review of Development Economics. Vol 6. Pp. 163-182.

[9] Berger, Peter. 1975. The Social Construction of Reality. Penguins Books: Australia

[10] Cohen, S. 2001. In Good Company: How Social Capital Makes Organization Work. London: Harvard Business Press.

[11] Theresia, dkk. 2015. Pembangunan Berbasis Masyarakat. Bandung : Alfabeta.

[12] Avison, D., R. Baskerville, and M. Myers. 2001. Controlling Action Research Projects. Information Technology and People, Vol. 14, No. 1. 